\title{
THE BEST IN LAW
}

\section{Conflict of Laws}

Second Edition

\section{J. G. Collier}

This clear and authoritative introduction to the principles of a complex and rapidly changing area of English law now appears in a revised and updated form, with a completely new chapter on Trusts. It will continue to be a valuable text for students and practitioners alike.

\section{Cambridge Studies in International} and Comparattve Law

45545-6 Hardback \$79.95/£55

45550-2 Paperback \$39.95/£24.95

\section{Democracy in}

\section{International Law}

James Crawford

This inaugural lecture examines the ways in which international law may or may not underwrite democratic principles, a subject that has increased greatly in significance in the post-Cold War world search for a "New World Order." 46835-3 Paperback $\$ 7.95 / £ 4.95$

\section{European Community Law and National Law: Cases on Their Relationship Andrew Oppenheimer, Editor} This is the first casebook devoted entirely to the relationship between European Community law and the national laws of the Member States. It contains some ninety decisions of both the Community's Court of Justice and the national courts of the twelve Member States, translated into English wherever necessary. Its ease of reference, with concise summaries, keyword headings preceding every case, and an alphabetical digest, makes the volume both a comprehensive reference work and a detailed introduction to the working relationship between Community law and national law.

47296-2 Hardback about $\$ 225.00 / £ 125$

\section{Justice in International Law}

Selected Writings of

Judge Stephen M. Schwebel

Stephen M. Schwebel

Judge Stephen M. Schwebel has been a highly-respected member of the International Court of Justice since 1981. This volume brings together thirtysix of his legal articles and commentaries of continuing interest.

46284-3 Hardback $\$ 145.00 / £ 80.00$

\section{The International Law on Foreign Investment \\ M. Sornarajah}

This book contains a survey of the Public International Law applicable to the protection of foreign investment. It examines the different techniques that have been adopted by various States for attracting foreign investment as well as for ensuring that foreign investment serves their economic objectives.

46528-1 Hardback $\$ 100.00 / £ 80$

\section{The Refugees Convention, 1951 \\ The Travaux Preparatoires Analysed with a Commentary by Dr. Paul Weis Paul Weis}

This book provides the first authoritative commentary on Articles 2-37, in which the rights of refugees were also enshrined in 1951. Both a commentator on the travaux preparatoires and a former refugee, Paul Weis' direct participation in the process that led to the adoption of the Convention by the United Nations in 1951 has enabled him to provide an invaluable guide to the understanding of the text.

47295-4 Hardback about \$74.95/£50

\section{Regional Peacekeeping and International Enforcement: The Liberian Crisis \\ Marc Weller, Editor}

This book reproduces significant documents, many of which are not otherwise available, including statements of the parties to the conflict, official documents emanating from ECOWAS detailing its peace-keeping efforts, and materials relating to the involvement of the United Nations and humanitarian organisations in the conflict. A substantive introduction provides a detailed analysis of the legal issues raised by this controversial operation.

47754-9 Hardback $\$ 89.95 / £ 50$

\section{Available in bookstores or from

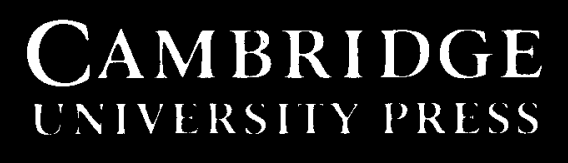

40 West 20th St., N.Y., NY 10011-4211

Call toll-free 800-872-7423

MasterCard/VISA accepted. Prices subject to change. 
American

Journal of

International

Law

\section{Cumulative Index 1981-1990}

With over 12,000 entries, this ten-year index to the AJIL is thorough and highly specific in its coverage. The Table of Cases pinpoints the location of over 800 cases that have been discussed over the course of a decade in the AJIL. The Subject Index displays headings in bold-faced print, in addition to alphabetically listing the title of articles and the names of authors.

In this age of computerized research, the Cumulative Index is also a useful companion to researchers conducting online searches of some 10,000 pages on either LEXIS $^{\oplus}$ or WESTLAW ${ }^{\bullet}$.

For all concerned with international law and international relations, the new Cumulative Index is unquestionably an indispensable and authoritative resource.

\section{Order Form}

Please send me ___ copies of the AJL Cumulative Index 1981-1990 at \$50 each plus postage* "(For postage and handling otargen, pleome add 20\% of your total ordor.)

Index Amount: Postage/Handling: Total Amount:

$\square$ Check enclosed (payable to ASIL) $\square$ Visa $\square$ Mastercand Signature Card No. Exp. Date

Shipping Address (please print):

ASIL Publications, 2223 Massachusetts Ave., NW - Washington, DC 20008-2864 (202) $939-6000 \square$ Fax (202) 797-7133

AIIL1094 


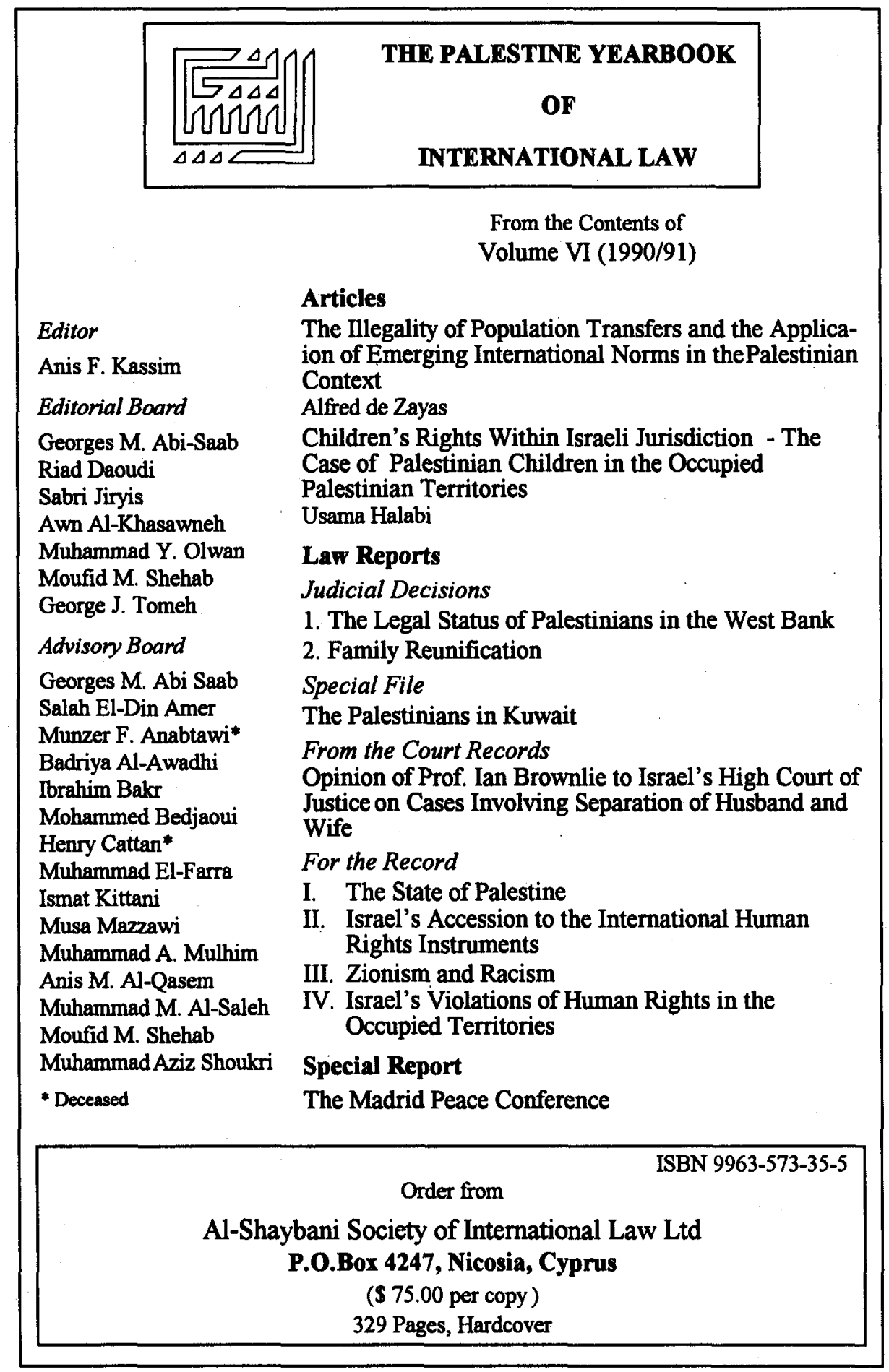




\section{Issue Papers on World Conferences}

The lssue Papers on World Conferences offer information of interest to government officials, representatives of non-governmental organizations and other individuals on the conduct and outcome of the conferences. The conferences are selected for the cross-cutting character of the topic addressed and for the opportunity to develop international legal frameworks. The lssue Papers are a cost-effective method of providing important materials in a timely fashion to decision-makers, the media and the public.

Please send me: copies of International Conference on Population and Development, Nadine Taub, 1994 (No.1) at \$10 each* copies of Extending the Non-Proliferation Treaty: Legal

Questions Faced by the Parties in 1995, George Bunn, 1994 (No.2) at \$10 each* 3 3 copies of Incorporating Human Rights into the Work of the World Summit for Social Development, James Paul, 1994 (No.3) at \$10 each* - _ copies of Towards an International Convention on Housing Rights: Options at Habitat II, Scott Leckie, 1994 (No. 4) at \$15 each.*

Future Issue Papers will be drawn from meetings on: Women, Beijing, September 4-15, 1995 Racial Discrimination, New York, January 10, 1996

Please enter a standing order for the above Issue Papers (you will be billed).

*(For postage and handling charges, please add $20 \%$ of your total order)

Amount:

Postage/Handling:

Total Amount:

S

s

S

Check enclosed (payable to ASIL)

$\checkmark$ Visa $\triangle$ Mastercard, Signature:

Card no Exp. Date

Shipping Address (please print clearly):

\section{THE AMERICAN SOCIETY OF INTERNATIONAL LAW} 2223 Massachusetts Avenue, NW - Washington, DC 20008-2864

AJIL 1094 (202) $939-6000=\mathrm{Fax}(202) 797-7133$ 


\section{RECENT RELEASES \\ SELECTED INFORMATION MATERIALS \\ $\star$ \\ DEPARTMENT OF STATE}

\section{PUBLICATIONS}

\section{CUMULATIVE DIGEST OF UNITED STATES PRACTICE IN INTERNATIONAL LAW, 1981-1988. BOOK I.}

Book I of the Cumulative Digest of United States Practice in International Law, 1981-1988 (xvi, 1311), published by the Department of State, became available at the U.S. Government Printing Office in April. It includes materials on which work was first begun in 1989, as well as a number of articles originally submitted by its Editor, Marian Nash (Leich), to the Journal under "Contemporary Practice of the United States Relating to International Law".

The contents of the five chapters in Book I cover the following subjects: (1) International Law in General (nature; sources, relation to municipal law); (2) Subjects of International Law (states, continuity and succession of states, diplomatic relations and recognition, international organizations, self-governing and non-self-governing territories, trust and former trust territories, and other subjects of international law, such as Antarctica, Commission of the European Communities, insurgent movements (the Palestine Liberation Organization), Jerusalem, and the U.N. Council for Namibia); (3) The Individual in International Law (nationality, passports and other travel documents, aliens, refugees, extradition, and protection of human rights); (4) State Representation (diplomatic missions and embassy property, consular officers and consulates, special trade missions and trade delegations, and foreign agents); and (5) The Law of Treaties and Other International Agreements (conclusion and entry into force, observance, application, and interpretation, amendment and modification, invalidity, termination and suspension of operation, and executive agreements).

Although the work of many members of the Department's Office of the Legal Adviser, past and present, is embodied in various documents without specific attribution, the authorship of all direct Digest contributions is identified by the initials of the drafters, who included members of other U.S. Government departments or agencies. Full names appear in the Introduction. The work product of the Legal Advisers themselves is also indicated.

Send orders to: Superintendent of Documents

U.S. Government Printing Office

Tel. No. 1-202-783-3238

P.O. Box 371954

Fax. No. 1-202-512-2250

Pittsburgh, Pa. 15250-7954

If sent by mail, orders should be accompanied by check or money order for $\$ 45.00$, made payable to the Superintendent of Documents. Remittances from outside the U.S. may be made by international postal money order or by draft on a U.S. bank. Orders by phone or fax, whether domestic or international, may use credit cards (Mastercard or Visa only).

(Cumulative Digest of U.S. Practice in International Law, 1981-1988, Book I, Stock No. 044-000-02394-6, \$45.00.)

All earlier volumes are out of print. 


\section{Human Rights: An Agenda for the Next Century}

Louis Henkin and John Lawrence Hargrove, Editors

The end of the Cold War has transformed the international human rights agenda for centuries to come. It has made it possible to take a fresh look at what half a century has done with the human rights idea, and has raised hopes of developing additional rights as well as more effective international enforcement of established rights. At the same time, it has spawned new conflicts, which have brought terrible events calling urgently for new means of responding to massive human rights violations. This 524-page book is the work of a group convened to study issues addressed at the UN World Conference on Human Rights held in Vienna in June 1993. It provides a basis for recommendations to the World Conference and to U.S. officials for action in response to the challenges facing the world at the turn of the century.

\section{GET YOUR COPY TODAY!}

Please send me _copies of this latest in the series of Studies in Transnational Legal Policy at $\$ 20.00$ each.*

*(For postage and handling charges, please add $20 \%$ of your total order.)

Amount:

Postage/Handling:

Total Amount:

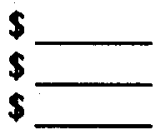

Check enclosed (payable to ASIL)

$\square$ Visa $\square$ MasterCard, Signature:

Card No.

Shipping Address (please print): Exp. Date

ANIL1094

The American Society of International Law 2223 Massachusetts Avenue, NW = Washington, DC 20008-2864 (202) 939-6034 = Fax (202) 797-7133 


\section{SPRINGER FOR INTERNATIONAL LAW}

Max-Planck-Institute for International Law

Prepared By: R. HOFMANN, J. KOKOTT, K.OELLERS-FRAHM,

S. OETER and A. ZIMMERMAN

\section{WORLD COURT DIGEST}

\section{Volume I: 1986-1990}

This current volume presents the important issues of international law, covering the period of 1986-1990. The compilation of this reference is a new start of an old activity of the Max-Planck-Institute for Foreign Public Law and International Law. Since 1931, a Digest of the Decisions of the Permanent Court and later, the International Court of Justice has been published. The last volume appeared in 1990 covering the period of 1976-1985. In the World Court Digest, the general pattern of the earlier volumes has been maintained but a few important changes should be noted. The parts of the judgements or separate opinions reproduced are frequently longer, to make it easier for the reader to see the context of a specific statement. Separate opinions are being reproduced in a restrictive manner, only where they concern essential points of a judgement. The World Court Digest should prove to be a valuable reference for all those involved with international law.

\section{o Springer-Verlag New York}

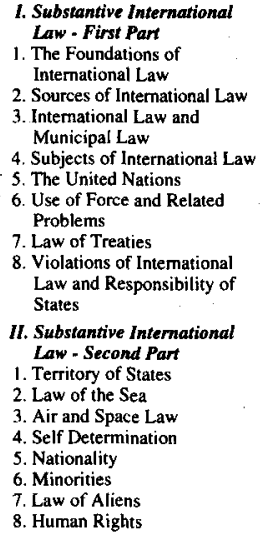

1. The Foundations of

International Law

2. Sources of International Law

3. International Law and

Municipal Law

4. Subjects of International Law

5. The United Nations

Use of Force and Related

Problems

7. Law of Treaties

8. Violations of Intemational

Law and Responsibility of

States

II. Substantive International

Law - Second Part

. Law of the Sea

3. Air and Space Law

4. Self Derermination

4. Self Determination

6. Nationality

7. Minorities

8. Human Rights

1992/309 PP./HARDCOVER/\$64.00/ISBN 0-387.56141-2

ORDER TOOAV:

CNI: Toll-Free 1-800-SPRINGER: $1800-777-4643$ in NJ call 201-348-4033 (8:30 AM-5:30 PM EST). - WhIE: Send payment

plus $\$ 2.50$ po 18.30 AM5.30 plus $\$ 2.50$ postage and handing for the first book and $\$ 1.00$ for each additional book to: Spniger Nerlas New Yonk, Inc.., Dept.

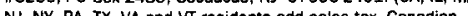
$N J, N Y, P A, T X, V A$ and $V$ residents add sales tax, Canadian residents add $7 \%$ GST. REFERENCE \#: $\$ 236$

\section{RECONCEIVING REALITY:}

WOMEN AND INTERNATIONAL LAW

\section{Dorinda G. Dallmejer, Editor}

This study provides in-depth coverage of feminist analysis of international hw, the public/private distinction in $\mathbf{l a w}$ and its impact on women's issues, and feminist approaches to issues of war and peace.

Please send _ copies of at $\$ 18.00$ each, plus $20 \%$ postage/handling.* Total Amount:

$\square$ Check enclosed (payable to ASIL)

$\square$ Visa $\square$ Master Card, Signature:

Card No.

Shipping Address (please print):

Exp. Date

\section{AJI1094}

\section{THE AMERICAN SOCIETY OF INTERNATIONAL LAW 2223 Massachusetts Avenue, NW W Washington, DC 20008-2864 (202) 939-6034 — Fax (202) 797-7133}




\section{a NEW $\square=$ \\ FROM THE AMERICAN SOCIETY OF INTERNATIONAL LAW \\ ASIL BULLETIN: Educational Resources on International Law}

The brand new ASIL BULLETIN series brings you special materials of interest from programs, workshops and publications of the American Society of International Law. The first four Bulletins are listed below. They represent important resources for research and classroom use. Professors, librarians and students will find them helpful.

\section{av}

No. 1. Taking International Law Seriously. Louis Henkin. 1994

No. 2. The Relevance of Law in the Study and Practice of International Relations. 1994

No. 3. Basic Documents of International Economic Law Online. 1994

No. 4. What's Online in International Law. Paul Zarins. 1994

Each of these Bulletins is offered for only $\$ 5.00$, plus $20 \%$ shipping and handling!

— Please send me additional copies of Bulletin $\# 1, \# 2$, $\# 3$, or $\# 4$, for $\$ 5$ each

$+20 \%$ postage \& handling.

(please circle)

Ship to:

TOTAL:

Return order form, with payment, to:

The American Society of International Law

2223 Massachusetts Avenue, NW

Washington, DC 20008

(202) $939-6000=$ Fax (202) 797-7133 


\title{
OXFord UNIVERSITY PRESS
}

\section{Yearbook of \\ International Environmental Law}

\author{
Volume 4 \\ Edited by GÜNTHER HANDL \\ Wayne State University Law School
}

Established in 1990 and now published by Oxford University Press, this major Yearbook draws contributors from around the world to provide the most reliable, up-to-date, and comprehensive review of internationally significant developments in environmental law. A "Year-in-Review" section summarizes year-by-year trends and each volume also features a documents section, a bibliography, and theoretical articles and book reviews. As part of an attempt to increase awareness of the subject throughout the world, Oxford University Press has more than halved the price of the Yearbook.

\section{0 pp. $\$ 120.00$}

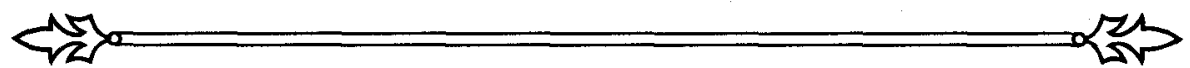

\section{Charter of the United Nations}

\section{A Commentary \\ Edited by BRUNO SIMMA, University of Munich}

Written as a guide to the U.N. Charter for practicing lawyers as well as scholars, and originally published to wide acclaim in German, the Commentary provides an article-by-article account of the legislative history, interpretation, and practical application of each Charter provision, and is the first commentary in any language to take into account the complete workings of the U.N. The English translation has been fully revised and updated since the appearance of the German edition, with most of the articles updated to November 1993. At once scholarly, authoritative, and immensely practical, this single volume will make a significant impact on the ways in which the U.N. Charter is discussed and understood.

\section{December 19941000 pp. $\$ 195.00$}

Prices are subjed to change and apply only in the U.S.

To order by phone using major credit cards, please call 1-800-451-7556.

In Canada, please call 1-800-387-8020. 


\section{ThE AMERICAN SOCIETY OF INTERNATIONAL LaW 89Th ANNUAl MeEting}

\section{-STRUCTURES OF WORLD ORDER}

\section{APRIL 5-8, 1995 - WALDORF-ASTORIA $\square$ NEW YORK, NY}

DON'T misS the 1995 ANNUAL MEETING. PANEL tOPICS WLL INCLUDE: BROADENING ACCESS TO INTERNATIONAL LAW THROUGH NEW TECHNOLOGIES; CURRENT ISSUES IN MULTINATIONAL FINANCING; TOPICAL ISSUES IN INTERNATIONAL SECURITIES; REGIONAL INSTITUTIONS IN EAST ASLA AND THE PACIFIC: IS THE TIME RIPE?; UN PEACEKEEPING: AN EARLY RECKONING OF THE SECOND GENERATION; HUMAN RIGHTS: IMPLEMENTATION THROUGH THE UN SYSTEM; AFRICA: MANY CHALLENGES, MUCH HOPE; CAPITALISM IN TRANSITION: THE ROLE of INTERNaTIONAL LaW; THE COSTS aND BENEFITS OF ECONOMIC SANCTIONS: THE BOTTOM LINE; THE BREAKDOWN OF WEAPONS CONTROL REGIMES?; THE CHALLENGE OF INTERNATIONAL REGULATORY COMPETTTON: TRADE AND COMPETITION; WHEN THE QUEST FOR CULTURAL OBJECTS DIVIDES NORTH FROM SOUTH; LAW OF THE SEA: THE CONVENTION ENTERS INTO FORCE; AND MUCH MORE. SPECLAL EVENTS INCLUDE A RECEPTION AT THE UNITED NATIONS, A POSTER SESSION ENTITLED "GALLERY OF IDEAS", A "MEET THE AUTHOR" SESSION, AND THE ANNUAL DINNER.

\section{SPEAKERS INCLUDE: \\ - The Honorable Boutros Boutros-Ghali -}

Secretary-General, United Nations.

- The Honorable HaNs Corell

Under-Secretary-General for Legal Affairs and The Legal Counsel, United Nations.

- The Honorable Madeleine K. Albright

U.S. Ambassador to United Nations (invited).

- OVER 35 TOP INTERNATIONAL EXHIBITORS

- Cle Credits available

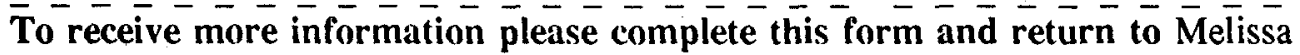

Scott, ASIL Meetings Manager, ASIL, 2223 Massachusetts Avenue, NW,

Washington, DC 20008-2864.

Name:

Organization:

Address:

City: State:

Country: Zip: 


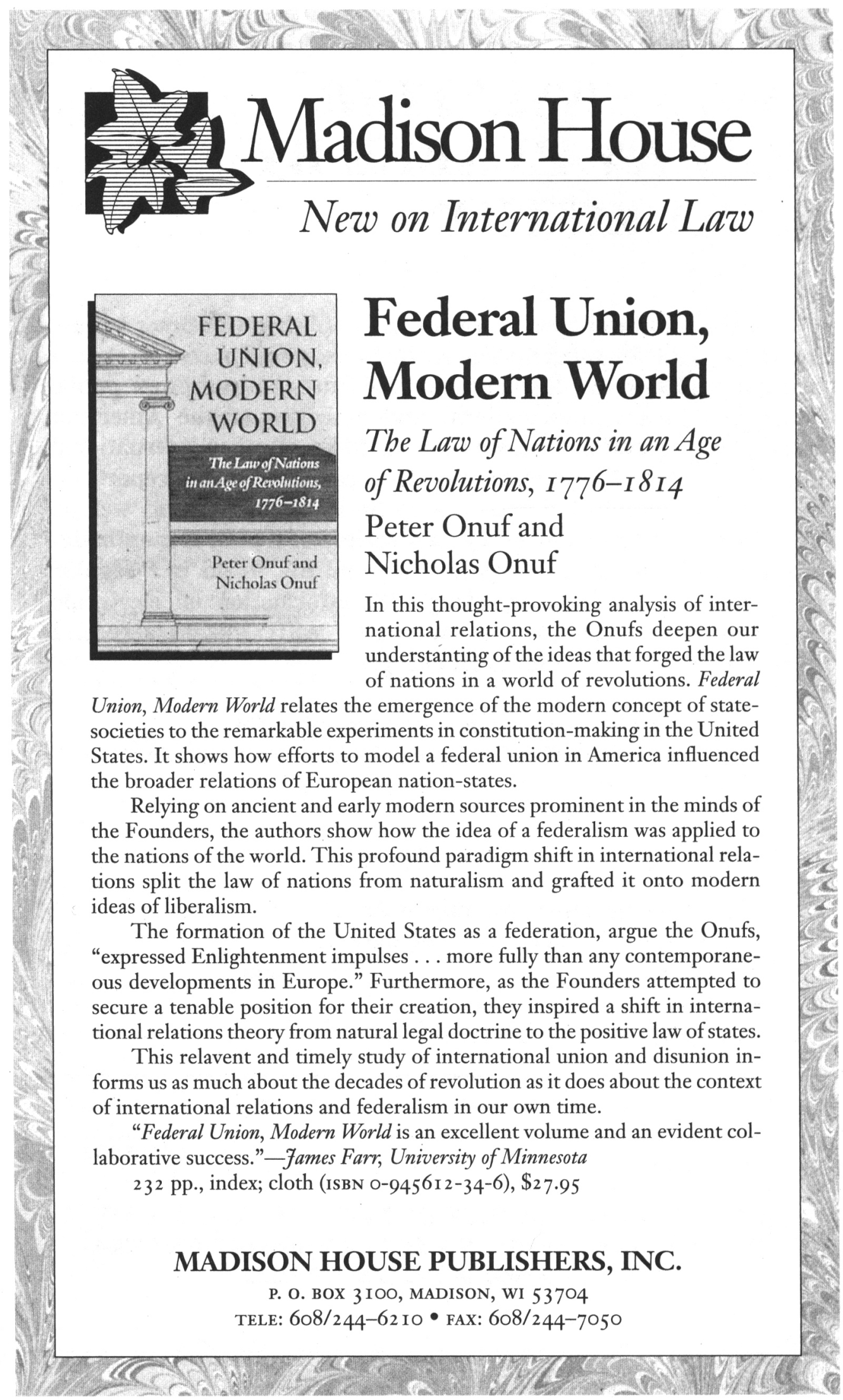




\section{ASIL NEWSLETTER NOW AVAILABLE BY SUBSCRIPTION}

The informative ASIL Newsletter, published five times a year, is now available by subscription. ASIL Newsletter reports on selected international law developments and informs the interested public about conferences, publications, and activities of the American Society of International $\mathrm{Law}$ as well as those of other international organizations. ASIL Newsletter regularly carries in-depth reports on the work of selected UN activities by Society observers, as well as thought-provoking commentary on a variety of topics. A months-inadvance calendar of meetings held around the world is a regular feature of ASIL Newsletter, along with information on electronic resources of international law materials. ASIL members receive ASIL Newsletter at no additional charge.

YES, please enroll me as a regular subscriber to ASIL Newsletter for $\mathbf{\$ 2 0}$ inside the U.S., $\mathbf{\$ 2 5}$ outside the U.S.

Amount:

$\$$

Check enclosed (payable to ASIL)

Visa $\square$ Master Card, Signature:

Card No. Exp. Date

Shipping Address (please print):

THE AMERICAN SOCIETY OF INTERNATIONAL LAW 2223 Massachusetts Avenue, NW $\square$ Washington, DC 20008-2864 (202) 939-6000 $\square$ Fax (202) 797-7133 


\title{
Help is on the way.
}

Searching for Foreign Legal Information?

\author{
Introduction \\ to Foreign \\ Legal Systems \\ Richard A. Danner and \\ Marie-Louise H. Bernal, Editors \\ - 1994 \\ - ISBN:0-379-21350-8 \\ - 456 pgs. \\ $\$ 85.00$
}

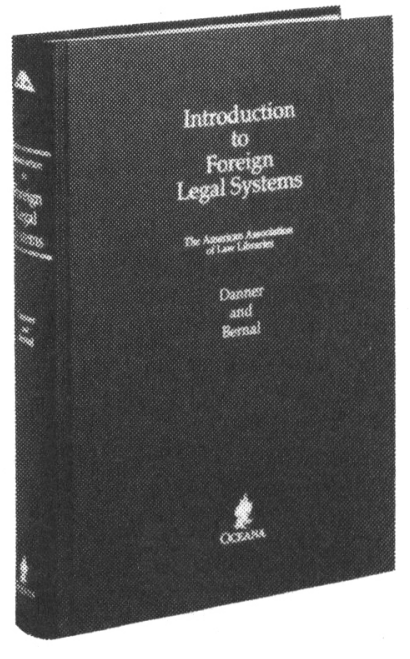

Introduction to Foreign Legal Systems, the valuable new work from the American Association of Law Libraries (AALL) and Oceana Publications, has been designed specifically with you in mind.

This is a text written by subject area specialists, it is not a collection of proceedings! Introduction to Foreign Legal Systems is the outgrowth from the first AALL/Oceana research institute (Winter ' 93$)^{\star}$. It provides in-depth analysis and expert guidance on accessing information. You will now be able to locate the right resources easily and skillfully.

Topics include:

\section{* Comparing Legal Systems}

* Resources for foreign law researchers

* Foreign Law Collection Building

(including translation problems/sources \&

acquisition of materials from difficult jurisdictions)
* African Legal Systems

* Asian Legal Systems

* Civil Law Systems

(including France \& Mexico)

* In an effort to provide law librarians with instruction on foreign legal systems and legal research in foreign, comparative and international law, the AALL and Oceana have just concluded three in a series of five co-sponsored institutes. Texts from each institute are being co-published by the AALL and Oceana. This series is an essential for anyone building or completing an international collection of legal materials, or needs source information or expert guidance on research techniques. Introduction to Foreign Legal Systems, the first institute's publication is being met with critical acclaim by law librarians nationwide. Look for the forthcoming publications from the second and third institutes: Introduction to International Organizations (Summer '93) and Transnational Legal Transactions (Summer '94); and mark your calendar for the fourth research institute which will focus its attention on international taxation and business, to be held July 1995 in Philadelphia, PA.

To order or to receive a complimentary copy of our catalog of current legal materials call, write, or fax:
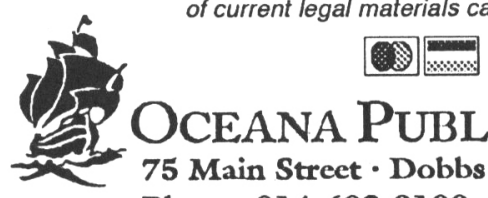

OCEANa Publications InC.

75 Main Strect $\cdot$ Dobbs Ferry, NY $\cdot 10522$

Phone: 914-693-8100 - Fax: 914-693-0402

or use our Catalog Internet Address:

via Gopher: "gopher oceana.infor.com 4700"

via Telnet: "telnet oceana.infor.com" Login: "oceana" (no password) $T M$

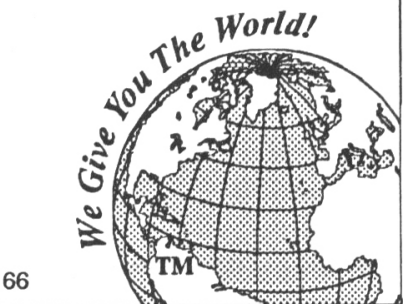




\section{INTERNATIONAL LEGAL MATERIALS}

Have the facts before the secondary sources provide the analysis, on all the important questions on international legal documents!

Reach an objective understanding of current issues by examining the official texis of treaties, legislation, court decisions, declarations, draft proposals, and memoranda that affect international relations and global interdependence. Background notes and content summaries accompany the documents.

International Legal Materials is published six times a year and indexed annually.

Order your copy now:

$\$ 80$ for ASH members; $\$ 100$ outside U.S. A. $\$ 138$ airmail $\$ 160$ for non members, $\$ 180$ outside U.S. A. \$ $\$ 218$ airmail

Back issues are available upon request@ $\$ 30$ each plus $20 \%$ postage and handling.

SEND TO:

Name

Address

Gity

State

Zip

Country

Amount Enclosed 8

Check (make payable to ASIL)

Visa Mastercard

H.

Signature

Exp. Date

N111 109

The American Society of International Law

2223 Massachuseits Avenue, NW

Washington, DC 20008-2864

(202) 939-6000; FAX (202) 797-7133 


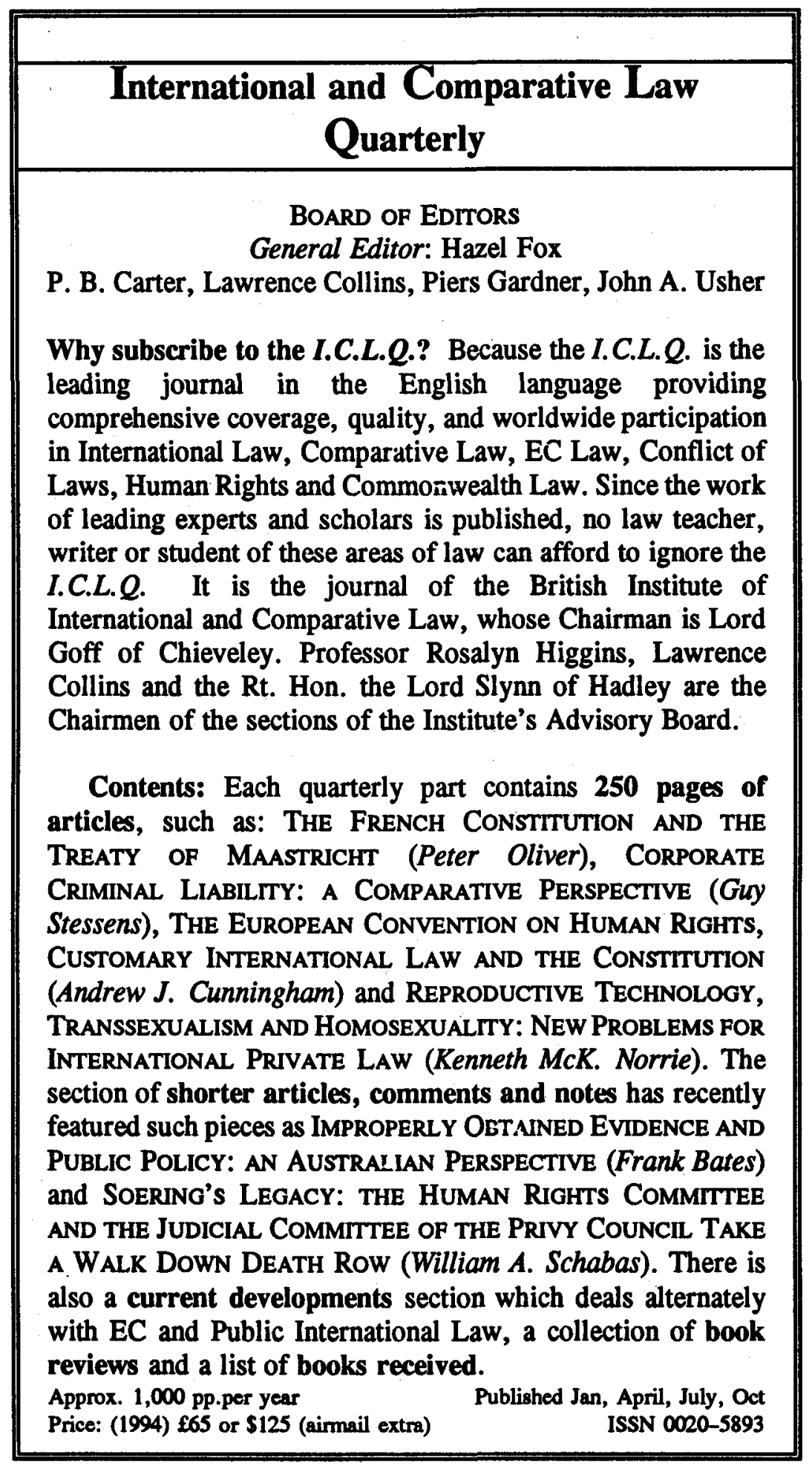




\section{THE AMERICAN SOCIETY OF INTERNATIONAL LAW}

\section{$\mathbf{B} \cdot \mathbf{E} \cdot \mathbf{N} \cdot \mathbf{E} \cdot \mathbf{F} \cdot \mathbf{I} \cdot \mathbf{T} \cdot \mathbf{S} \quad \mathbf{O} \cdot \mathbf{F}$ \\ PUBLICATIONS \\ Members receive the American Journal of International Law, the leading quarterly in the field, and the ASIL Newsletter, and are entitled to substantial discounts on the Society's documentary, International Legal Materials, the Annual Meeting Proceedings, and on books pub- lished under ASIL auspices.}

\section{INTEREST GROUPS . .}

- Antarctica

- Armed Conflict

- Dispute Resolution in International Contracts

- International Economic Law

- Human Rights

- Indigenous Peoples
$\mathbf{M} \cdot \mathbf{E} \cdot \mathbf{M} \cdot \mathbf{B} \cdot \mathbf{E} \cdot \mathbf{R} \cdot \mathbf{S} \cdot \mathbf{H} \cdot \mathbf{I} \cdot \mathbf{P}$

\section{MEETINGS}

The four-day Annual Meeting is the Society's premier event, affording members the opportunity to discuss a broad range of topics in panels, seminars and workshops. Regional meetings and special joint conferences provide additional fora for analyzing current legal issues.
- International Organizations
- Law in the Pacific Region
- Private International Law
- Southern Africa
- International Space Law
- Wildlife Law
- Women in International Law

. . bring members together through meetings and workshops, and generate newsletters and other publications.

Membership is open to persons of all nationalities and professions who are interested in the challenging problems of law and policy in the international legal order. For more information, or to receive an application, call or write to the address below. 


\section{THE AMERICAN SOCIETY OF INTERNATIONAL LAW - MEMBERSHIP APPLICATION 2223 Massachusetts Avenue, NW, Washington, DC 20008-2864. (202) 939-6000 Be sure to check membership type on reverse side.}

\begin{tabular}{|c|c|}
\hline Last Name & First Name \\
\hline \multicolumn{2}{|l|}{ Organization } \\
\hline \multicolumn{2}{|l|}{$\overline{\text { Street }}$} \\
\hline City & State \\
\hline Zip/Postal Code & Country \\
\hline Telephone & E-Mail \\
\hline
\end{tabular}

Mal sent to: $\square$ business address $\square$ home address
Membership is on a calendar year basis, and includes the ASIL Newsletter and the American Joumal of Intemational Law.

New members will promptly receive a Membership Centificate with a Member Profile to indicate your interests and how you would like to participate in Sociery activities.

\begin{tabular}{l} 
Home/Permanent Address \\
\hline Street, P.O. Box, etc. \\
\hline City, State, Zip \\
Country Telephone/Fax/E-Mail \\
Students: Provide copy of student I.D. or verification of status from an administrator at your school.
\end{tabular}

Students: Provide copy of student I.D. or verification of status from an administrator at your school. Year of Graduation

for postage outside the U. S.* = \$

"Your AJLL is delivered via surface mail. If you would like fasser detivery ourside the U.S., enclose $\$ 15$ postage.

Exp. Date

\section{THE AMERICAN SOCIETY OF INTERNATIONAL LAW - MEMBERSHIP APPLICATION 2223 Massachusetts Avenue, NW, Washington, DC 20008-2864. (202) 939-6000 Be sure to check membership type on reverse slde.}

\begin{tabular}{|c|c|}
\hline Last Name & First Name \\
\hline \multicolumn{2}{|l|}{ Organization } \\
\hline \multicolumn{2}{|l|}{ Street } \\
\hline City & State \\
\hline Zpopostal Code & Country \\
\hline Telephone & E-Mail \\
\hline
\end{tabular}

Mail sent 10 : $\square$ business address $\square$ home address
Membership is on a calendar year basis, and includes the ASIL Newsletter and the American joumal of Intemational Law.

New members will promply receive a Membership Certificate with a Member Profile to indicare your interests and how you would like to participate in Society activities.

Home/Permanent Address

Street, P.O. Box, etc.

\section{Ciry, Srate, Zip}

Country Telephone/Fax/E-Mail

Students: Provide copy of student l.D. or verification of status from an administrator at your school. Year of Graduation: Exp. Date

\section{THE AMERICAN SOCIETY OF INTERNATIONAL LAW - MEMBERSHIP APPLICATION 2223 Massachusetts Avenue, NW, Washington, DC 20008-2864. (202) 939-6000 Be sure to check membership type on reverse side.}

\begin{tabular}{lll}
\hline Last Name & First Name \\
\hline Organization & \\
\hline Street & State \\
\hline City & Country \\
\hline Zip/Postal Code & Fax & E-Mail
\end{tabular}

Mail sent to: $\square$ business address $\square$ home address

I enclose $\$$ for dues, $s$ for Interest Group fees, and \$ for postage outside the U.S.* = $\$$

"Your AIlL is delivered via surface mail. If you would like faster delivery outside the U.S., enclose \$15 postage. Exp. Date

Membership is on a calendar year basis, and includes the ASIL Newsletter and the American Joumal of International Law.

New members will promptly receive a Membership Certificate with a Member Profile to indicate your interests and how you would like to participate in Society activities.

Home/Permanent Address
Street, P.O. Box, etc.
City, State, Zip

\section{Country Telephone/Fax/E-Mail}

Srudents: Provide copy of student 1.D. or verification of status from an administrator at your school. Year of Graduation: 
MEMBERSHIP STATUS (check one)

$\square \quad$ Regular Members $\$ 95$ a year Individuals, regardless of nationality or profession.

$\square \quad$ Intermediate Members $\$ 65$ a year Individuals who are under 30 years of age at the time of application for membership may be Intermediate Members for the first three consecutive years of membership.*

$\square \quad$ Retired Members $\$ 55$ a year Individuals who are retired and who are 70 years of age or older.*

$\square \quad$ Special Members $\$ 55$ a year. (A) Individuals whose gross annual income is under $\$ 35,000$. Please state income with payment.

(B) Individuals who reside in developing countries and whose economic circumstances warrant Special Membership. Please direct request to the Executive Director with payment.

JOIN SOCIETY INTEREST GROUPS

Check below, and enclose annual fee

$\square$ \5 Antarctic Law, Politics and Resource Policy

Student Members $\$ 30$ a year.

Requires verification of student status (see instructions on reverse)

$\square \quad$ Contributing Members $\$ 180$ a year.

$\square \quad$ Supporting Members $\$ 300$ a year.

$\square \quad$ Annual Patrons $\$ 750$ a year

$\square \quad$ Patrons One-time payment of $\$ 7,500$.

D. Corporate Members $\$ 2,000$ a year Consult the Society staff about the many benefits of this membership.

$$
\text { (31) }
$$

$\$ 7$ Dispute Resolution in Intemational Commercial Contracts (32)

$\$ 5$ Rights of Indigenous Peoples (33)

$\$ 10$ Intemational Economic Law (34)

\$8 International Environmental Law (35)

$\$ 12$ Human Rights (36)

$\$ 5$ Intemational Organizations (37)

$\$ 5$ Private International Law (38)

$\$ 5$ Law in the Pacific Region (39)

$\$ 10$ International Space Law (40)

$\square 5$ Women in International Law (41)

$\$ 5$ Wildlife Law (42)

$\$ 5$ Southem Africa (43)

$\$ 5$ lieber Society on the law of Armed Conflict (44)

$\square \$ 5$ U.N. Decade of International Law (45)

$\square 5$ Arms Control and Nonproliferation (46)

$\square 5$ Status of Minorities and Other Communities (47)

$\square \$ 5$ International Criminal Law (48)

$\square$ \$6 Young Members (49)

*Date of Birth

\section{MEMBERSHIP STATUS (check one)}

$\square \quad$ Regular Members $\$ 95$ a year. Individuals, regardless of nationality or profession.

$\square \quad$ Intermediate Members $\$ 65$ a year. Individuals who are under 30 years of age at the time of application for membership may be Intermediate Members for the first three consecutive years of membership.*

$\square \quad$ Retired Members $\$ 55$ a year. Individuals who are retired and who are 70 years of age or older.*

$\square \quad$ Special Members $\$ 55$ a year (A) Individuals whose gross annual income is under $\$ 35,000$. Please state income with payment.

(B) Individuals who reside in developing countries and whose economic circumstances warrant Special Membership. Please direct request to the Executive Director with payment.
JOIN SOCIETY INTEREST GROUPS.

Check below, and enclose annual fee

$\square$ \$5 Antarctic Law, Politics and Resource Policy (31)

$\square$ \$7 Dispute Resolution in Intemarional Commercial Contracts (32)

Requires verification of

\section{Contributing Members $\$ 180$ a year.}

Supporting Members $\$ 300$ a year.

Annual Patrons $\$ 750$ a year.

Patrons One-time payment of $\$ 7,500$.

Corporate Members $\$ 2,000$ a year Consult the Society staff about the many benefits of this membership. $\square \$ 5$ Rights of Indigenous Peoples (33)

$\square 10$ Intemational Economic Law (34)

$\square \$ 8$ International Environmental Law (35)

$\square \$ 12$ Human Rights (36)

$\square$ \$5 International Organizations (37)

$\square \$ 5$ Private International Law (38)

$\square 5$ Law in the Pacific Region (39)

$\square \$ 10$ Intemational Space Law (40)

$\square \$ 5$ Women in Intemational Law (41)

$\square 5$ Women in Internation
$\square 5$ Wildlife Law (42)

$\square \$ 5$ Southem Africa (43)

\$5 Lieber Society on the Law of Armed Conflict (44)

$\square \$ 5$ U.N. Decade of International Law (45)

$\square \$ 5$ Arms Control and Nonproliferation (46)

$\square \$ 5$ Status of Minorities and Other Communities (47)

$\square \$ 5$ International Criminal Law (48)

$\square \$ 6$ Young Members (49)

*Date of Birth

\section{MEMBERSHIP STATUS (check one)}

$\square \quad$ Regular Members $\$ 95$ a year.

Individuals, regardless of nationality or profession.

$\square \quad$ Intermediate Members $\$ 65$ a year. Individuals who are under 30 years of age at the time of application for membership may be Intermediate Members for the first three consecutive years of membership.*

$\square \quad$ Retired Members $\$ 55$ a year

Individuals who are retired and who are 70 years of age or older. *

$\square \quad$ Special Members $\$ 55$ a year. (A) Individuals whose gross annual income is under $\$ 35,000$. Please state income with payment.

(B) Individuals who reside in developing countries and whose economic circumstances warrant Special Membership. Please direct request to the Executive Director with payment.
JOIN SOCIETY INTEREST GROUPS.

Check below, and enclose annual fee

$\square$ \$5 Antarctic Law, Politics and Resource Policy (31)

Requires verification of student status (see instructions on reverse)

$\square \quad$ Contributing Members $\$ 180$ a year.

$\square \quad$ Supporting Members $\$ 300$ a year

$\square \quad$ Annual Patrons $\$ 750$ a year.

$\square \quad$ Patrons One-time payment of $\$ 7,500$.

Corporate Members $\$ 2,000$ a year. Consult the Society staff about the many benefits of this membership. $\square \$ 7$ Dispute Resolution in International Commercial Contracts (32)

$\square$ \$5 Rights of Indigenous Peoples (33)

[ $\$ 10$ Intemational Economic Law (34)

$\square \$ 8$ International Environmental Law (35)

$\square \$ 12$ Human Rights (36)

$\square \$ 5$ Intemational Organizations (37)

[] $\$ 5$ Private Intemational Law (38)

$\square$ Law in the Pacific Region (39)

$\square$ \$10 Intemational Space Law (40)

$\square \$ 5$ Women in Intemational Law (4l)

$\square \$ 5$ Wildlife Law (42)

$\square \$ 5$ Southem Africa (43)

$\square$ \$5 Lieber Society on the Law of Amed Conflict (44)

$\$ 5$ UN Decade of Intemational Law (45)

$\square$ \$5 Arms Control and Nonproliferation (46)

$\square \$ 5$ Status of Minorities and Other Communities (47)

$\$ 5$ International Criminal Law (48)

$\square \$ 6$ Young Members (49) 


\section{THE AMERICAN SOCIETY OF INTERNATIONAL LAW - MEMBERSHIP APPLICATION 2223 Massachusetts Avenue, NW, Washington, DC 20008-2864. (202) 939-6000 \\ Be sure to check membership type on reverse side.}

\begin{tabular}{lll}
\hline Last Name & First Name \\
\hline Organization & \\
\hline Street & State \\
\hline City & Country \\
\hline Telephostal Code & Fax & E-Mail \\
Mail sent to: $\square$ business address &
\end{tabular}

Mail sent to: $\square$ business address $\quad \square$ home address
Membership is on a calendar year basis, and includes the ASIL Newsletter and the American Joumal of Intemational Law.

New members will promptly receive a Membership Certificate with a Member Profile to indicate your interests and how you would like to participate in Society activities.

\begin{tabular}{ll}
\hline Home/Permanent Address & \\
\hline Screet, P.O. Box, etc. & \\
\hline City, State, Zip & Telephone/Fax/E-Mail
\end{tabular}

Students: Provide copy of scudent I.D. or verificarion of status from an administrator at your school. Year of Graduation

I enclose $\$$ for dues, $\$$ for Interest Group fees, and \$ for postage outside the U. S.* = $\$$

"Your AJL is delivered via surface mail. If you would like laster deivery ourside the U.S., enclose $\$ 15$ postage. $\square$ Check enclosed (payable to The American Society of International Law) $\square$ VISA $\square$ Mastercard Card No. Exp. Date

\section{THE AMERICAN SOCIETY OF INTERNATIONAL LAW - MEMBERSHIP APPLICATION 2223 Massachusetts Avenue, NW, Washington, DC 20008-2864. (202) 939-6000 \\ Be sure to check membership type on reverse side.}

\begin{tabular}{lll}
\hline Last Name & First Name \\
\hline Organization & \\
\hline Street & & \\
\hline Ciry & State \\
\hline Zip/Postal Code & Country \\
\hline Tetephone $\quad$ Fax & E-Mail & \\
Mail sent to: $\square$ business address & $\square$ home address & \\
& &
\end{tabular}

Mail sent to: $\square$ business address $\square$ home address
Membership is on a calendar year basis, and includes the ASIL Newsletter and the American Joumal of intemational Law.

New members will promptly receive a Membership Certificate with a Member Profile to indicate your interests and how you would like to participate in Society activities.

\section{Home/Pemanent Address}

Street, P.O. Box, etc.

\section{Cicy, State, Zip}

\section{Country:}

Telephone/Fax/E-Mail

Students: Provide copy of student L.D. or verification of status from an administrator at your school. Year of Graduation:
1 enclose $\$$ for dues, $\$$ for Interest Group fees, and \$ for postage outside the U.S.* $=\$$

"Your AJlL is delivered via surface mail. If you would like faster delivery outside the U.S., enclose \$15 postage. Exp. Date

\section{THE AMERICAN SOCIETY OF INTERNATIONAL LAW - MEMBERSHIP APPLICATION 2223 Massachusetts Avenue, NW, Washington, DC 20008-2864. (202) 939-6000 \\ Be sure to check membership type on reverse side.}

\begin{tabular}{|c|c|}
\hline $\overrightarrow{\text { Last Name }}$ & First Name \\
\hline \multicolumn{2}{|l|}{ Organization } \\
\hline \multicolumn{2}{|l|}{$\overline{\text { Street }}$} \\
\hline City & State \\
\hline$\overline{\text { Zip/Postal Code }}$ & Country \\
\hline Telephone & E-Mail \\
\hline
\end{tabular}

Mail sent to: $\square$ business address $\square$ home address

I enclose $\$$ for dues, $\mathbf{s}$ for Interest Group fees, and \$
Membership is on a calendar year basis, and includes the ASIL Newsletter and the American Joumal of Intemational Law.

New members will promptly receive a Membership Certificate with a Member Profile to indicate your interests and how you would like to participate in Society accivities.

Home/Permanent Address

Street, P.O. Box, etc.

\section{City, State, Zip}

Country Telephone/Fax/E-Mail

Students: Provide copy of student I.D. or verification of status from an administrator at your school. Year of Graduation Exp. Date 
MEMBERSHIP STATUS (check one)

- Regular Members $\$ 95$ a year. Individuals, regardless of nationality or profession

$\square \quad$ Intermediate Members $\$ 65$ a year, Individuals who are under 30 years of age at the time of application for membership may be Intermediate Members for the first three consecutive years of membership. *

$\square \quad$ Retired Members $\$ 55$ a year Individuals who are retired and who are 70 years of age or older.*

- Special Members $\$ 55$ a year. (A) Individuals whose gross annual income is under $\$ 35,000$. Please state income with payment.

(B) Individuals who reside in developing countries and whose economic circumstances warran Special Membership. Please direct request to the Executive Director with payment.

JOIN SOCIETY INTEREST GROUPS

Check below, and enclose annual fee .

Student Members $\$ 30$ a year Requires verification of student status (see instrucrions on reverse)

ㄷ Contributing Members $\$ 180$ a year

$\square \quad$ Supporting Members $\$ 300$ a year.

$\square \quad$ Annual Patrons $\$ 750$ a year.

$\square \quad$ Patrons One-time payment of $\$ 7,500$

$\square \quad$ Corporate Members $\$ 2,000$ a year. Consult the Society staff about the many benefits of this membership. $\square \$ 5$ Antarctic Law, Politics and Resource Policy (31)

$\square \$ 7$ Dispute Resolution in International Commercial Contracts (32)

$\$ 5$ Rights of Indigenous Peoples (33)

- $\$ 10$ International Economic Law (34)

$\square$ \$8 International Environmental Law (35)

$\square \$ 12$ Human Rights (36)

口. $\$ 5$ International Organizations (37)

- $\$ 5$ Private Intemational Law (38)

$\square 5$ Law in the Pacific Region (39)

$\square$ \$10 International Space Law (40)

$\square \$ 5$ Women in Intemational Law (41)

口 $\$ 5$ Wildlife Law (42)

$\square 5$ Southern Africa (43)

$\square \$ 5$ Lieber Society on the Law of Armed Conflict (44)

$\$ 5$ U.N. Decade of Intemational Law (45)

$\square \$ 5$ Arms Control and Nonproliferatión (46)

$\square \$ 5$ Status of Minorities and Other Communities (47)

55 Intemational Criminal Law (48)

\$6 Young Members (49)

*Date of Birth

\section{MEMBERSHIP STATUS (check one)}

$\square \quad$ Regular Members $\$ 95$ a year Individuals, regardless of nationality or profession.

$\square \quad$ Intermediate Members $\$ 65$ a year. Individuals who are under 30 years of age at the time of application for membership may be Intermediate Members for the first three consecutive years of membership. *

$\square \quad$ Retired Members $\$ 55$ a year. Individuals who are retired and who are 70 years of age or older. *

$\square \quad$ Special Members $\$ 55$ a year (A) Individuals whose gross annual income is under $\$ 35,000$. Please state income with payment

(B) Individuals who reside in developing countries and whose economic circumstances warrant Special Menbership. Please direct request to the Execurive Director with payment
JOIN SOCIETY INTEREST GROUPS.

Check below, and enclose annual fee

$\square \$ 5$ Antarctic Law, Politics and Resource Policy (31)

Requires verification of student status (see instructions on reverse).

Contributing Members $\$ 180$ a year.

Supporting Members $\$ 300$ a year

Annual Patrons $\$ 750$ a year.

Patrons One-time payment of $\$ 7,500$.

$\square \$ 7$ Dispute Resolution in Intermational Commercial Contracts (32)

$\square \$ 5$ Rights of Indigenous Peoples (33)

[ $\$ 10$ Intemational Fconomic Law (34)

$\square \$ 8$ International Environmental Law (35)

$\square$ \$12 Human Rights (36)

$\square \$ 5$ International Organizations (37)

$\square \$ 5$ Private International Law (38)

$\square \$ 5$ Law in the Pacific Region (39)

- \$10 Intemational Space Law (40)

$\square 5$ Women in Intemational Law (41)

$\square \$ 5$ Wildlife Law (42)

Consult the Society staff about the many benefits
Cong of this membership.

$\$ 5$ Southem Africa (43)

\$5 Lieber Society on the Law of Armed Conflic: (44)

$\square 5$ U.N. Decade of International Law (45)

$\$ 5$ Arms Control and Nonproliferation (46)

$\$ 5$ Status of Minorities and Other Communities (47)

$\square$ \$5 Intemational Criminal Law (48)

$\square \$ 6$ Young Members (49)

*Date of Birth

\section{MEMBERSHIP STATUS (check one)}

$\square \quad$ Regular Members $\$ 95$ a year. Individuals, regardless of nationality or profession.

$\square \quad$ Intermediate Members $\$ 65$ a year. Individuals who are under 30 years of age at the time of application for membership may be Intermediate Members for the first three consecutive years of membership.*

$\square \quad$ Retired Members $\$ 55$ a year. Individuals who are retired and who are 70 years of age or older. ${ }^{*}$

$\square \quad$ Special Members $\$ 55$ a year (A) Individuals whose gross annual income is under $\$ 35,000$. Please state income with payment.

(B) Individuals who reside in developing countries and whose economic circumstances warran Special Membership. Please direct request to the Executive Director with payment.
JOIN SOCIETY INTEREST GROUPS

Check below, and enclose annual fee

$\square \$ 5$ Antarctic Law, Politics and Resource Policy (31)

Requires verification of student status (see instructions on reverse).

[ Contributing Members $\$ 180$ a year

Supporting Members $\$ 300$ a year.

Annual Patrons $\$ 750$ a year

Patrons One-time payment of $\$ 7,500$.

Corporate Members $\$ 2,000$ a year. Consult the Society staff about the many benefits of this membership. $\square \$ 7$ Dispute Resolution in International Commercial Contracts (32)

$\square \$ 5$ Rights of Indigenous Peoples (33)

\$10 International Economic Law (34)

\$8 International Environmental Law (35)

$\$ 12$ Human Rights (36)

] $\$ 5$ Intemational Organizations (37)

$\$ 5$ Private International Law (38)

$\$ 5$ Law in the Pacific Region (39)

$\$ 10$ International Space Law (40)

$\square \$ 5$ Women in Intemational Law (41)

$\square \$ 5$ Wildlife Law (42)

$\square \$ 5$ Southern Africa (43)

$\square \$ 5$ Lieber Society on the Law of Armed Conflict (44)

$\square \$ 5$ U.N. Decade of International Law (45)

$\$ 5$ Ams Control and Nonproliferation (46)

$\square \$ 5$ Status of Minorities and Other Communities (47)

$\square \$ 5$ International Criminal Law (48)

$\square \$ 6$ Young Members (49) 


\section{Freedom for}

\section{the Seas in the}

\section{1st Century}

Ocean Governance

and Environmental

Harmony

\section{Edited by Jon M. Van Dyke, Durwood Zaelke, and Grant Hewison}

Published by Island Press

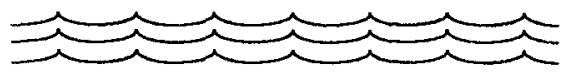

Co-Winner of the 1994 Sprout Award for best book on intemational environmental affairs

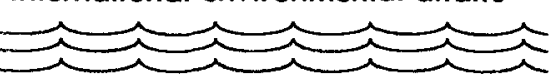

"At last-a book that can jolt mankind out of the dangerously optimistic attitude that the oceans are infinitely resilient. Readers will be inspired. Shining through the entire volume is a resounding sea change in attitude, a shift from mankind's self-centered terrestrial view to a perspective that acknowledges the overwhelming importance of the sea to our species-and all of life on Earth."

- Dr. Sylvia A. Earle, former Chief Scientist, National Oceanic and Atmospheric Administration, and holder of the world record for deepest untethered dive

"By explicitly focusing on that part of international law which is based in idealist theories, this book is less interested in examining the is than outlining the ought or the possible. Its thesis that the Convention on the Law of the Seas has within it sufficiently radical components that could be an engine of transforming international relations is a provocative and important approach."

- Leonard P. Hirsh, International Liaison, Office of International Relations, Smithsonian Institution in announcing Freedom for the Seas in the 21st Century as the co-winner of the 1994 Sprout Award for best book on international environmental affairs.

"This book provides signposts for the future preservation of our oceans. To ignore them is to continue the current crisis in ocean governance." - Sir Geoffrey Palmer, former Prime Minister of New Zealand

Freedom for the Seas in the 21st Century brings together leading international experts on marine policy to address current threats to the health of the seas and to offer new approaches to the challenge of protecting our marine environment. The paradigm presented is one of ocean governance rather than of law or policy; it challenges the prevailing concept of "freedom of the seas" and calls instead for a governing notion of "freedom for the seas" where the primary goal is in the protection of ecological vitality. Topics covered include:

- strategies for controlling ocean pollution

- regulation of high-seas fishing

- defects in current deep seabed mining regulatory provisions

- threats to the marine environment posed by military activities

Jon M. Van Dyke is Professor of Law at the University of Hawaii and Director of the University of Hawaii Institute for Peace.

Durwood Zaelke is President of the Center for International Environmental Law and Adjunct Professor of Law at American University.

Grant Hewison is a Law Fellow at CIEL.

Available in bookstores or call 1-800-828-1302; outside the US (707) 983-6432

8:00 a.m.-5:00 p.m. Pacific Coast Time

Island Press

Box 7, Dept. 4IL, Covelo, CA 95428 


\title{
FORDHAM UNIVERSITY SCHOOL OF LAW
}

\section{MASTER OF LAWS PROGRAM}

\author{
LL.M. degrees in:
}

\author{
BANKING, CORPORATE \& FINANCE LAW \\ $\&$ \\ INTERNATIONAL BUSINESS \& TRADE LAW
}

The Graduate Program of Fordham University Law School offers two courses of study leading to graduate degrees. Students may pursue either course of study on a full or parttime basis.

International business and trade law, along with banking, corporate and finance law, are vitally important and expanding areas of law today, given the interdependence of the United States and its trading partners and the convergence of the banking, corporate, insurance and other financial sectors. Fordham Law School has developed special resources and expertise in these areas. Fordham University School of Law has been the leading U.S. center for the study of European Community Law for two decades. It is also one of the few law schools in the country with advanced curriculum in banking law and regulation.

The Graduate Program is limited to forty students, full and part-time, in any academic year. For a catalogue and application contact:

\section{Graduate Program Fordham University School of Law 140 West 62 nd Street Room 429 New York, New York 10023}

or call (212) 636-6883

(fax) (212) 636-6899 